\title{
The Role of Translation in Developing ESP Learners' Reading Comprehension Skills- A Case Study of Medical Students at Najran University-KSA
}

\author{
Ismail Mohammed Hamid Rushwan \\ English Department-College of Science and Arts-Najran University, Saudi Arabia \\ E-mail: rushwan80@yahoo.com
}

Received: 09-12-2016

Published: 01-05-2017
Accepted: 26-01-2017

doi:10.7575/aiac.ijalel.v.6n.3p.243
Advance Access Published: March 2017

URL: http://dx.doi.org/10.7575/aiac.ijalel.v.6n.3p.243

\begin{abstract}
Reading comprehension is developed through successful interaction between the reader and the text. This interaction is the major factor that plays the crucial role in comprehension. ESP has a strong and palpable presence in the curricula of Saud universities due to a range of considerations. It is used in different domains such as medicine, engineering, and allied health. It is well known, that any use of L1 in English language instruction has always been a matter of hot debate. This study aims to shed some fresh light on the importance of translation as a pedagogical tool in developing reading comprehension skills of ESP medical learners at Najran University- KSA. Undeniably, the students experience bewilderment and great difficulties in grasping the enormous quantity of medical terms and texts as a result of their extreme weakness in English. The level of most Saudi students in English is very low and their knowledge of vocabulary is extremely limited. Studying medical terminology is the foundation for studying any health-related field. Medicine has a language of its own, and mastering it is a complex task. So, regarding ESP medical courses, the students resort to machine translation, because they cannot absorb the medical texts and terms properly. There are so many shortcomings with respect to machine translation This study investigates the effect of using translation in ESP medical classes with the objective of helping students in comprehending terminologies and texts. It also aims at motivating them and meeting their learning needs. Moreover, the study aims to help students concentrate on the standardized terminology and avoid the imperfections of machine translation.
\end{abstract}

Keywords: Translation, ESP, Reading Comprehension, Machine Translation

\section{Introduction}

Translation means rendering the meaning of a text into another language in the way that the author intended the text; (Newmark, 1988:5).Whereas reading comprehension is the process of simultaneously extracting and constructing meaning through interaction with written language, Sweet \& Snow (2003). As for English for Specific Purposes (ESP), it is defined as an approach to language teaching which aims to meet the needs of particular learners, (Hutchinson \& Waters, 1987: 21). The main goal of reading is to train students to read efficiently and quickly enough to get information or meaning from written material rapidly and with full understanding. There are many reasons why getting students to read English texts is an important part of a teacher's job. Reading can help students to be able to read texts in English either for their careers, for study purposes, or simply for pleasure. It is useful for other purposes too. Any exposure to English- provided that, the students understand it more or less- is a good thing for language learning. Research indicates that the use of translation in reading comprehension enhances learning (Mahmoud: 2006). Recently, there has been a revival of interest to translation due to the shift of its emphasis- to using mother tongue as a resource for the promotion of language learning, translation develops three qualities essential to all language learning: accuracy, clarity, and flexibility (Ross, 2000:61).

\subsection{Statement of the problem}

Arab medical students encounter great difficulties in grasping ESP texts in general and ESP medical texts and terms in particular. Due to their low level in English, they resort to machine translation in order to understand terminologies and texts. This MT, most of the time mislead them further and land them in trouble. The researcher deemed translation as a remedy for learners' problems. It was in recognition of that need that he conducted this study. Obviously, there is a lack of research on ESP disciplines, especially, medical reading comprehension. Most ESP teachers find the scientific content difficult to tackle in depth. Although the ESP approach is widely used in English language programs in Saudi Arabia, but few studies had been conducted about it. The purpose of these programs is to provide students with an English Language knowledge that enables them to join the workforce. Attention is increasingly being paid to pedagogy in ESP classrooms and a debate is on as to how it should be taught. 
Undoubtedly, the majority of students find great difficulty and suffer immensely in understanding and getting the utmost benefit from these courses which are relevant to their needs. This study attempted at figuring out how the use of translation can facilitate and enhance reading comprehension skills as far as ESP medical learning is concerned.

\subsection{Research Questions}

The following questions are considered the problem of the research:

- What are the problems that face ESP medical learners and hurdle their progress in terms of reading comprehension?

- What is the impact of translation on facilitating learning and grasping medical terms?

- What are ESP medical learners' attitudes towards the use of L1 in their classes?

- How can the use of L1 help in avoiding the imperfections of machine translation?

\subsection{Research Hypothesis}

The study is intended to achieve the following aims:

1. To explore the role translation can have on reading comprehension of ESP medical students.

2. To emphasize the role of translation in understanding medical texts, medical terms and abbreviations

3. To find out the effect of translation on raising students' competence and performance, and help them be updated with medical terminology

4. To pinpoint and correct the mistakes made by the students as a result of their use of MT.

5. To contribute to the learning of EFL students, in general, and ESP students, in particular.

\subsection{Significance of the Study}

This study was targeting all the parties involved in the process of ESP medical learning. It targets the learners as they are the ultimate goal of the whole educational process as well as the ESP teachers. It is also significant to syllabi designers who develop material for ESP courses. It can also clear the way for other researchers to shed light on translation and its relevance to ESP.

\section{Relevant Literature}

A lot of literature has been written about reading comprehension in general, reading comprehension in ESP medical classes, and translation and its relevance to reading. Good readers use comprehension strategies to facilitate the construction of meaning. These strategies include understanding vocabulary in the present context, skimming, scanning, predicting, summarizing, and evaluating, self-questioning, making connections, visualizing and monitoring etc. Researchers believe that using such strategies helps students become meta-cognitive readers (McLaughlin \& Allen, 2002.). In his research "Translation: Back from Siberia", carried out at Azad University in Iran, Bonyadi (2006), reached the conclusion that translation activity in our classrooms enhances interaction between teacher and students and among the students themselves.

The reasons behind students' use of L1 in the classroom are numerous. Harmer, (2001: 131) indicates that the choice of task has made the use of L1 almost inevitable for students. In this respect, Eldridge (1996: 210), indicates that another reason why students use their own language in the classroom is because it is an entirely natural thing to do. When students learn a foreign language, they use translation almost without thinking about it, particularly at elementary and intermediate levels. (Newmark,1988:46) said that communicative translation is original for its successful shift from learning translation as a set of skills to using translation as a resource.

Harbord (1992: 354), advocates and shared the same ideas with Eldridge and says:

Students use their L1 when performing pedagogical tasks, especially when one student is explaining something to another. This is a habit that in most cases will occur without the teacher's encouragement.. (Galina, 2010) in her paper titled "New Trends Exploring the language of Science" conducted in Russia stated that the amount of the native language the students need depends on their proficiency and linguistic situations.

(Hutchinson and Waters, 1987: 111) state that comprehension in ESP texts is essential in creating a context of knowledge for the comprehension of the input. Ghazala (2008:156) stated that, Arabization is the translation of technical terms into Arabic. It is one of the central problems not only for students, but also for teachers as well as for translators. (Mahmoud, 2002: 5), Translation can improve comprehension since it encourages the students to read a passage carefully and precisely at the word, sentence and text levels. According to Harding (2007:7), an ESP teacher is also a course designer and material provider. In his research "ESP Learners' Needs": A Case Study of Medical Students at Some Sudanese Universities", Dafa-Allah (2012) reached a conclusion that what the medical students need more is Academic English. Learners are the main resource of data in the needs analysis and the failure of most ESP programs in Sudan is directly attributed to the absence of needs analysis practice. 


\section{Methodology}

The methodology consisted of the setting, research subjects, measuring instruments, and procedures. The methods adopted in this study are the true experimental design, in which the students targeted are involved in the experiment, and the questionnaire tool. Two comparable similar groups from Community College- Medical Laboratories Department- and the College of Community Service and Continuing Learning were selected particularly for experimentation purposes. They totaled (80) in number, (40) from each college.

\subsection{Limitation of the Study}

The topic of the research was limited to the role of translation on developing ESP learners' reading comprehension skills. The subjects of the study were limited to the students of two colleges at Najran University-KSA. The study was conducted during the academic year 2013-2014.

\subsection{Instruments of Data Collection}

The subjects of the study were ESP learners studying different medical disciplines at Najran University-KSA, along with (20) faculty members. The researcher used three instruments to collect the appropriate data for the research as follows:

- Survey instrument

- Experimental instrument

- Questionnaire instrument

Questionnaires were used as an instrument for investigating the attitudes of ESP teachers about the effect of translation in ESP medical classes. As for the experimental method, the target population (80) students from two different colleges at $\mathrm{NU}$, who represented control and experimental groups, sat for a test on a broad area of comprehension skills. The aim of the test was to reach a conclusion about the benefit students can get from the use of L1 in ESP medical reading comprehension classes. The sample of the research was composed of four groups as follows:

1. Two control groups from two separate colleges.

2. Two experimental groups from the same two colleges

3. A questionnaire distributed to a group of English Language staff members at Najran University - KSA, who have good experience of teaching English in general and ESP in particular in order to reach a conclusion about their opinions on using L1 in ESP medical classes.

\subsection{Description of the Test}

A 50-item reading comprehension test was developed for the experimental and control groups. This test was administered in order to determine the effect translation could have on the level and performance of the students. The test consisted of ten questions. Those ten questions represented the ten variables for the statistical analysis. They were syllabus-oriented questions prepared for (80) test takers. Table (1) demonstrates the scores of the students of Community College and Community Services alike. Needless to say, such statistics proved that those tests were adequately reliable for the purpose of the study. The experimental groups of the two colleges were subject to treatment. The program, which was concerned with comprehension skills such as scanning, skimming, context clues, predictions, inferences, references, and summarizing was taught by the researcher to the experimental groups of both colleges, while the two control groups remained treatment-free. The scores of the students were subject to statistical analysis (Mann-Whitney), in order to set the results' significance level of difference. The comparison of the results obtained from the performance of both the experimental and control groups helped to reach a conclusion about the significant difference. This reflected the effectiveness of the program in casting light on the study (the effect of translation on developing students' comprehension skills in ESP medical courses) and which group was supposed to do better. Also the results of the questionnaire distributed to a number of teachers showed that there is a strong tendency towards the use of L1 in ESP medical classes in order to ease the learning process and boost students' comprehension skills.

\subsection{Design and Analysis of the Program}

When the researcher embarked on designing this program of translation, he exerted a considerable effort into two main obstacles: medical knowledge, and medical terminology. Although translation of medical terms is an interesting and rich area of translation studies, but it also presents problems which are different from other specialized domains. These problems lie in the vast and complicated number of terms, newly introduced ones, and abbreviations. One of the most significant aspects of this program was to draw students' attention to the mistakes they made as a result of computer-aided translation, appendix (1), which constituted a kind of error analysis for Example-Based Machine Translation. By pinpointing those mistakes, and using the correct terms, they would be aware of avoiding them in the future. Translation of medical texts is always formal in style, and it requires professionalism and precision. So, in line with this, the researcher used to make sure that the Arabic version was formal, without colloquial features being used, so that it reflects the same function of the original. He followed the communicative method in translation, which is considered to be a real-life activity. 
Table 1. A Key showing Coefficient relation Value

\begin{tabular}{ccc}
\hline Variables & Coefficient correlation & Explanation \\
\hline 1 & $0---------0.3$ & A weak relation \\
\hline 2 & $0.31------0.50$ & A limited relation \\
\hline 3 & $0.51-------0.70$ & A good relation \\
\hline 4 & $0.71--------0.90$ & A strong relation \\
\hline 5 & $0.91------1.0$ & A very strong relation \\
\hline
\end{tabular}

Table 1. Shows the coefficient correlation. It is clear from the key above that the correlation of the test falls between $(\mathbf{0 . 9 1}$ _ 1.0).

The stronger the correlation, the more reliable the test is.

Table 2. Means and Standard Deviation of the Scores of the Students of CC and CS

\begin{tabular}{lllll}
\hline \multirow{2}{*}{ statistics } & Community & \multicolumn{3}{l}{ Services } \\
\cline { 2 - 5 } & Experimental & control & experimental & Control \\
\hline No. & 20 & 20 & 20 & 20 \\
\hline Mean & 36.6 & 17.1 & 36.1 & 18.05 \\
\hline variance & 63.2 & 75.674 & 81.322 & 80.682 \\
\hline S.D. & 7.949 & 8.699 & 9.017 & 8.982 \\
\hline
\end{tabular}

Table 2. Shows the means and Standard Deviation of the scores of the students in both EG and CG. As can be seen, all scoring of the EGs showed a statistically significant effect.

Table 3. The result of the analysis which reflects the validity of the test for Community College

\begin{tabular}{ll}
\hline Variables & Correlations \\
\hline Skimming for Main Ideas & $.913(* *)$ \\
\hline Scanning & $.773(* *)$ \\
\hline Multiple Meaning Words & $.672(* *)$ \\
\hline Context Clues & $.754(* *)$ \\
\hline Prefixes and suffixes & $.850(* *)$ \\
\hline Prediction & $.750(* *)$ \\
\hline Inference & $.795(* *)$ \\
\hline Cause and Effect & $.659(* *)$ \\
\hline Previewing & $.905(* *)$ \\
\hline Summarizing & $.503(*)$ \\
\hline
\end{tabular}

** Correlation is significant at the $\mathbf{0 . 0 1}$ level (2-tailed).

* Correlation is significant at the $\mathbf{0 . 0 5}$ level (2-tailed).

Table 4. The result of the analysis which reflects the validity of the test for Community Service

\begin{tabular}{ll}
\hline Variables & Correlations \\
\hline Skimming for Main Ideas & $.917(* *)$ \\
\hline Scanning & $.878(* *)$ \\
\hline Multiple Meaning Words & $.492(*)$ \\
\hline Context Clues & $.792(* *)$ \\
\hline Prefixes and suffixes & $.854(* *)$ \\
\hline Prediction & $.835(* *)$ \\
\hline Inference & $.838(* *)$ \\
\hline Cause and Effect & $.706(* *)$ \\
\hline Previewing & $.858(* *)$ \\
\hline Summarizing & $.569(* *)$ \\
\hline$* *$ Correlation is significant at the $\mathbf{0 . 0 1}$ level (2-tailed). & \\
$*$ Correlation is significant at the $\mathbf{0 . 0 5}$ level (2-tailed). &
\end{tabular}




\subsection{The Format of the Questionnaires}

The researcher adopted the descriptive and analytical method. The structure of the teachers' questionnaire consisted of five "dimensions" and (32) statements, appendix (3).

\subsection{Feedback of the Teachers' Questionnaire}

Figure (1) shows the feedback of the teachers who took part in the questionnaire. For the first dimension "Most Students encounter difficulties in understanding medical terminologies" $85 \%$ of the respondents agreed with this point. As for the second dimension "Translation in ESP Medical Classes can be a good pedagogical tool" the respondents' opinion in this regard was (75\%). Regarding the third dimension of the questionnaire which is "The attitudes towards the use of translation in ESP medical classes are positive", the respondents' satisfaction was 70\%. Concerning the fourth dimension "By using translation in ESP medical classes, the students can avoid the shortcomings of machine translation", the percentage of the participants was also (70\%). And in respect to the fifth dimension "Translation of medical terms meets learners' needs" the respondents' opinion was $(65 \%)$. So, this result showed that faculty members are strongly in favor of a limited use of translation in ESP medical classes.

At the end of the questionnaire, there was a section for giving comments. Almost all the comments were in favor of a limited use of L1 in ESP medical classes. But only one respondent commented that he is not supportive of any use of L1 in an ESP class. He indicated that it does nothing to enhance a student's communicative ability in the language. Another respondent mentioned that, he commends the use of translation for level-one students, but it is never a good idea to use it when teaching advanced-level students. They have to study more so as to gain more knowledge in their chosen fields of endeavor. Regarding the second dimension of the questionnaire, statement (12) By "Using translation, the teacher can establish a close rapport with the students", a third respondent added a comment that this point is inappropriate. The last comment came from a respondent concerning the second dimension, statement (15) "The use of mother tongue in an ESP class would decrease rote learning" he disagreed with this statement pointing out that, L1 has nothing to do with rote learning, which is a bad habit, students developed in their earlier stages of learning.

Generally speaking, the opinions expressed in the comment section were a real plus and they enriched the content of this study.

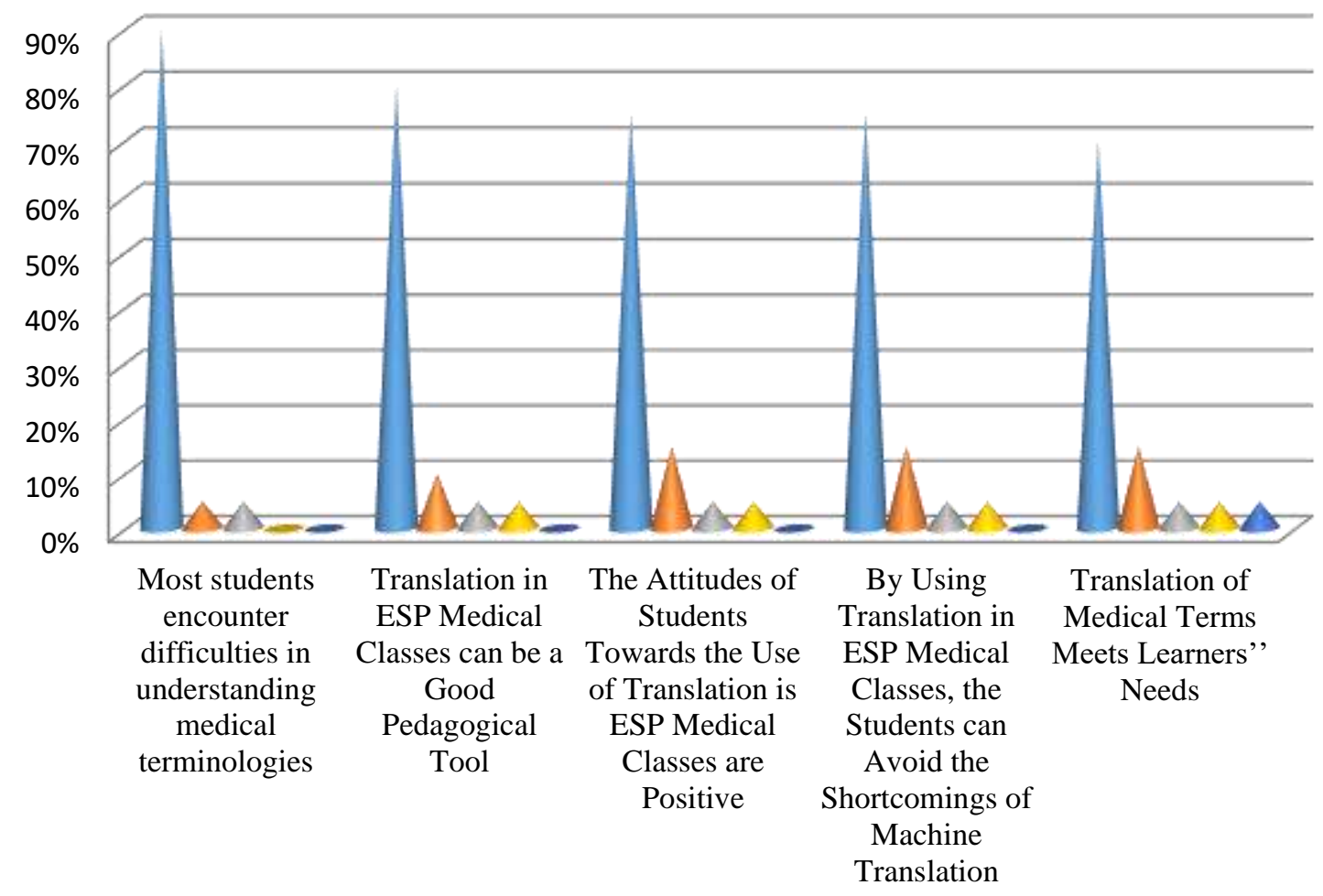

$\square$ Strongly Agree $\quad$ Agree $\quad$ Neutral $\quad$ Disagree $\quad \square$ Strongly Disagree

Figure 1. Teachers' Questionnaire

Figure (1) shows the feedback of the teachers who took part in the questionnaire.

\section{Discussion of the findings}

This study was devoted to a much-neglected area of ESP and medical terminology which is enjoying a revival of interest. In this research, it became clear that the use of translation in ESP medical classes is instrumental and beneficial for the learners. The performance of the two experimental groups of this study stands as evidence for this analysis. The use of L1 has also a pivotal role in motivating the students. Another important factor is that, it has been 
proofed that translation for ESP medical learners is in line with their learning needs. Moreover, the results of the teachers' and students' questionnaires add more strength to this idea.

In the researcher's humble opinion, translation of medical terms is necessary all the time, but, there are some situations when it is absolutely a must for every teacher. For example, Obsessive Compulsive Disorder (OCD) is defined as a mental health condition where a person has obsessive thoughts and compulsive behavior. The word "obsession" usually describes something enjoyable, but in OCD the obsession is unpleasant and frightening. It's almost impossible for the students to understand this long definition and get the required meaning. So, the Arabic translation for OCD, is (الوسواس القهري) the ideal solution to take the learners out of this dilemma. Another example is when the students took the word abortion for miscarriage. Abortion is the mother's murdering of an infant, or terminating the pregnancy by medical ways in cases like rape or some other medical reasons. Miscarriage is the spontaneous body's removal of the embryo or fetus with no outside influence because of either a problem with the fetus itself, a hormonal imbalance, a woman falling from the stairs, etc. So, the same word for both cases in Arabic is (إجهاض) ). In this case, the teacher's interpretation would remove students' confusion.

Considering the first research question: What are the problems that face ESP medical learners and hurdle their progress in terms of reading comprehension, as the result of the test shows and according to the researcher's experience in teaching ESP students, the problems that face them are the difficulty in understanding medical terminology and reading comprehension, plus their extremely limited vocabulary.

As a result, it can be concluded that the first hypothesis of the research: To explore the role translation can have on reading comprehension of ESP medical students; it is acceptable and in line with the core of the research. Some researchers also agreed with this idea, (Khajavifar, 1995) stated that, "Although translation is recommended to be used as a means only and not as an end, it is strongly advised that it should be used as an end for specific purposes". However, Carreress, (2006) put forward an argument against using L1 as a language teaching tool by stating that" Translation is an artificial exercise that has no place in communicative methodology. Also, it is restrictive in that it confines language practice to two skills only: reading and writing". Concerning the second research question; What is the impact of translation on facilitating learning and grasping medical terms? It is quite evident from the results of the tests and the feedback of the questionnaire that translation is a facilitating tool in this aspect. It also supports the second hypothesis; To emphasize the role of translation in understanding medical texts, terms and abbreviations. With regard to the third research question; What are the attitudes of ESP medical learners towards the use of L1 in their classes?, referring to the experimental groups, their involvement in the ESP medical classes was more than the control groups, their engagement in the learning process was better, and they deemed the lesson as stimulating and interesting. By these activities, students will have opportunities to develop confidence in their abilities and enhance their performance. This supports the idea that the use of translation in an ESP medical class motivates the students, and that their attitudes towards it are positive. Whereas, the students in the control groups encountered difficulties in understanding the texts and grasping the terminology. Their response was very little, and they were disengaged from class activities.

With reference to the fourth research question; How can the use of L1 help in avoiding the imperfections of machine translation? It is answered by the effort the researcher made in finding the proper translation for the medical terminology, see appendix (1). Obviously, it is in line with the fourth hypothesis; To pinpoint and correct the mistakes made by the students as a result of their use of MT, by correcting the mistakes and understanding the proper terminology, the students will be aware of using them correctly in future.

To assess the students' ability in translating a medical text, see appendix (2). The students translated by the help of machine translation, then the researcher translated it by himself, so that they can see the difference and try to adopt the right way in translation.

The following points could be a summary for the findings:

- The research findings reveal that, the use of translation as a pedagogical tool is absolutely vital and beneficial to develop ESP medical learners' comprehension skills.

- The performance of the experimental groups of the two colleges in this study far outstrip the performance of the control groups.

- Translation in ESP classes can be a boon not a bane, provided that it is used properly and to a certain extent.

- There is a far cry between the machine-translated medical texts and those translated by the researcher in terms of cohesion and semantic organization.

- Machine translation and bilingual dictionaries tantamount to misleading the students and landing them in trouble, because of the inaccuracy of MT and the numerous equivalents of a word.

- The students' attitudes towards the use of translation in an ESP class are positive. 


\section{Conclusion}

In this study, the researcher depended on experiment and convincing argument to nullify that the use of L1 must be strictly prohibited in teaching. The students are not only weak in English, with a low command of vocabulary, but they are also terribly reluctant to learn it. The depth of content and complexity of medical terms are problems encountered by the majority of them. Whenever they come across a term, they resort to MT to check its meaning, and most of the time they are misled further. So, according to the researcher's point of view, a proper use of translation in an ESP medical class is a positive teaching tool and will also facilitate the learning process.

\subsection{Recommendations}

The researcher humbly came up with the following recommendations:

- Translation should be rendered highly significant for ESP medical learners in terms of developing comprehension skills.

- There is a dire need for translation in ESP medical classes due to the students' poor level in English.

- By a limited use of mother tongue, students would accumulate the heavy load of the specialized vocabulary.

- Syllabus designers are supposed to take into account the significance of translation in ESP medical courses.

- It's much advantageous that ESP medical teachers should be bilingual.

\subsection{Suggestions for Further Studies}

The following areas can be suggested for further research:

- It is deemed advisable to conduct research regarding ESP and its connection to translation in a multitude of other disciplines such as engineering, law, information technology, business administration, etc.

- There is a need for replication of the current study with different population samples in the kingdom, attempting it on a larger sample and with different groups of respondents in different institutions, so that the reliability of the adopted techniques could be enhanced.

- Materials provide models of correct and appropriate language use and help to organize the teachinglearning process. A future study could discuss the combination of materials and translation and how they can affect ESP courses.

\section{References}

Carreres, A. (2006, December). Strange bedfellows: Translation and language teaching. The teaching of translation into L2 in modern languages degrees: Uses and limitations. In Sixth Symposium on Translation, Terminology and Interpretation in Cuba and Canada. Canadian Translators, Terminologists and Interpreters Council.

Mahmoud, K. (2006). Translation and Foreign Language Reading Comprehension: A Neglected Didactic Procedure. English teaching Forum, 44(4).

Eldrige, E. (1996). Code-Switching in a Turkish secondary School. ELT Journal, 50(4).

Ghazala. P. (2008). Translation as Problems and Solutions. Dar Alilam Malayin, Beirut.

Galina, N. (2010). Linguistic and translation Studies in Scientific Communication. Peter Lang Publishing Group

Harding, D. (2007). English for Specific Purposes. Oxford University Press.

Harmer, D. (2005). The Practice of English Language1. Teaching, Longman.

Hutchinson \& Waters. (1987). English for Specific Purposes. Cambridge University Press.

Harbord, J. (1992). The use of the mother tongue in the classroom. ELT Journal, 46(4), 350-355.

Dafa-Allah. (2012). 'ESP Learners' Needs: A Case Study of Medicine Students at Some Sudanese Universities. English for Specific Purposes 12.

Khajavifar, F. (1995). The Relationship between Technical English Proficiency and Translation of Technical Texts. Retrieved. (2012). http://database.irandoc.ac.ir/DL/Digitization/Display_FullImage_FrameSet.aspx?DigitalCode=120

Mahmoud , A. (2000). Modern standard Arabic vs Non-standard Arabic: Where do Arab students transfer from?

Language.Culture and Curriculum, 13, 126-136.

McLaughlin, M., \& Allen, M.B. (2002). From Guided Comprehension: A Teaching Model for Grades 3-8 International Reading Association.

Newmark. (1998). A Textbook of Translation, Longman.

Ross, N. J. (2000). Interference and Intervention: Using Translation in the EFL Classroom. Modern English Teacher, 9 (3), 61-66.

Snow \&Sweet, A.P. (2003) Rethinking reading comprehension (PP.1-11) New York: Guilford Press.

Khajavifar, F. (1995). The Relationship between Technical English Proficiency and Translation of Technical Texts. Retrieved. (2012). http://database.irandoc.ac.ir/DL/Digitization/Display_FullImage_FrameSet.aspx?DigitalCode=120

Mahmoud, A. (2000). Modern standard Arabic vs Non-standard Arabic: Where do Arab students transfer from? 
Language, Culture and Curriculum, 13, 126-136.

McLaughlin, Maureen \& Allen, Mary Beth. (2002). From Guided Comprehension: A Teaching Model for Grades 3-8 International Reading Association.

Newmark. (1998). A Textbook of Translation, Longman.

Ross, N. J. (2000). Interference and Intervention: Using Translation in the EFL Classroom. Modern English Teacher, 9 (3), 61-66.

\section{Appendix 1}

\section{Examples of Error Analysis from Students' Computer aided Translated terms}

\section{Example-Based Machine Translation (EBMT)}

\begin{tabular}{|c|c|c|}
\hline Medical Terminology & Machine Translation & Correction \\
\hline 1. Renal Dialysis & 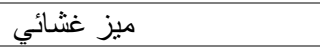 & غسيل كلوي \\
\hline 2.Oteoporosis & - تلين العظام & هشاشـة العظام \\
\hline 3.Vitiligo & ل & البرص \\
\hline 4.Dehydration & الزموهة & فقدان السو ائل \\
\hline 5.Stroke & ل & جلطة دماغية \\
\hline 6. Anesthesia & ـتخدير محلى & تخدير موضعي \\
\hline 7.Concussion & ل ل هزة & ارتجاج مخي \\
\hline 8.Orthodontics & طب الأسنان المعوجة & تقويم الأسنان \\
\hline 9. Palliative Medicine & الطب المخفف & الطب التلطفي \\
\hline 10. Cardiac Arrest & احتجاز قلبي & سكتة قلبية \\
\hline 11. Gonorrhea & التعقبية & السيلان \\
\hline 12.Syphilis & الافرنجى & ل الزهري \\
\hline 13. Angina & 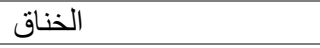 & ذبحة صدرية \\
\hline 14.Severe Heart Attack & هجوم القلب الثديد & نوبة قلبية حادة \\
\hline 15. Abortion & إسقاط & إجهاض بفعل فاعل \\
\hline 16. Miscarriage & ـ املاص & إجهاض عفوي \\
\hline 17. Ischemia & احتباسية & فقر دم موضعي \\
\hline 18. Internist & طبيب داخلي & طبيب باطني \\
\hline 19.Vertigo & ل & 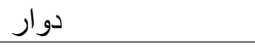 \\
\hline 20. Liposuction & مص الدهون & شفط الدهون \\
\hline 21. Colonic Volvulus & 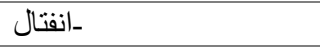 & التو اء القولون \\
\hline 22. Cirrhosis & تشمع دهنى & تليف الكبد \\
\hline 23. Hysopadias & مبال تحتاني & عيب خلقي تناسلي \\
\hline 24. Polycystic & أكياس المبايض & تكيس المبايض \\
\hline 25. Glaucoma & ل & الماء الأسود \\
\hline 26. Myopia & الخفش & قصر النظر \\
\hline 27. Residency & إقامة & فترة الامتياز \\
\hline 28.Venerology & الأمر اض الزهرية & الأمر اض التناسلية \\
\hline 29.Gastroenteritis & التهاب أمعاء & لز لزلة معوية \\
\hline 30. Vasoconstriction & تضييق الشر ايين & ضيق الأو عية الدموية \\
\hline 31. Stillbirth & ملاص & جنين مولود ميتا \\
\hline 32. Cystitis & المثن & ل التهاب المثانة \\
\hline 33. Thyroiditis & 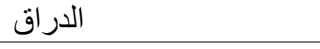 & التهاب الغدة الدرقية \\
\hline 34. Senility & سبه & ل \\
\hline 35. Litholopaxy & الرضخ & ــقتيت الحصاوى \\
\hline
\end{tabular}

\section{Appendix (2) Translation of a Text}

\section{New Treatment for Kidney Failure other than Dialysis}

With kidney failure, patients lose nearly all of their kidney function. Dialysis can do some of the kidney's work including removing extra fluids and wastes, regulating blood pressure, and so on. However, dialysis isn't an easy treatment even for the fittest person. Well then, are there new treatment for kidney failure other than dialysis? How does dialysis help treat kidney failure?

In addition to cleansing blood, maintaining electrolyte balance, keeping blood pressure and secreting some hormones are other key function. When kidney function level is less than $15 \%$, it indicates that the patient's condition has aggravated into kidney failure. Dialysis can replace the diseased kidney to eliminate small molecular waste products, such as creatinine, uric acid, and urea. From this point, we can know that dialysis is unable to work as effectively as a healthy kidney. What's worse is that, the longer the patient is on dialysis, the more complications he will develop. Alternative treatment for kidney failure: 
According to treatment requirements, we would like to introduce Micro-Chinese Medicine Osmotherapy. This therapy has the following therapeutic effects:

- Anti-inflammation: The onset of kidney failure has a close link with inflammatory factors in blood circulation. This effect can help prevent further kidney damage and normalize blood circulation.

- Anti-coagulation: Activating blood and removing stasis is a superiority of traditional Chinese medicine. This effect can prevent formation of thrombus, so as to deal with renal anoxia an ischemia

\section{A computer-aided translation for the text (New Treatment for Kidney Failure other than Dialysis)}

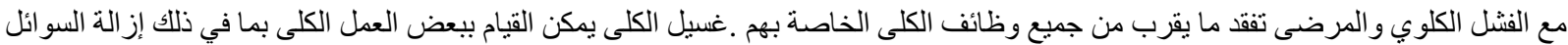

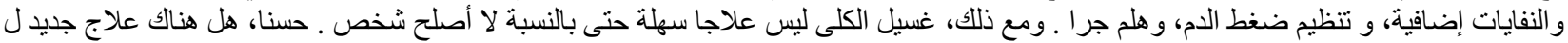

$$
\begin{aligned}
& \text { الفشل الكلوي بخلاف غسيل الكلى } \\
& \text { كيف يمكن مساعدة غسيل الكلى الفشل علاج الكلى ؟ }
\end{aligned}
$$

\section{The text "New Treatment for Kidney Failure other than Dialysis" Translated by the Researcher}

الغسيل عن "بدلا الكلوي للفشل جديد علاج

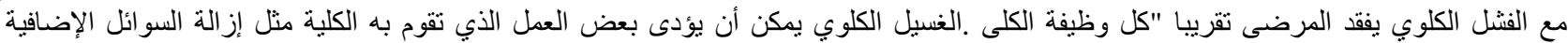

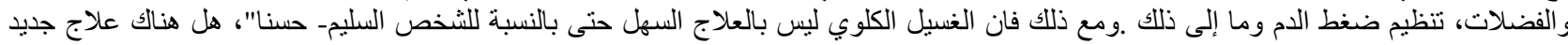

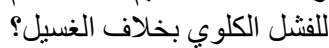

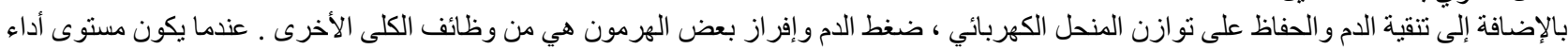

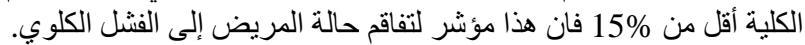

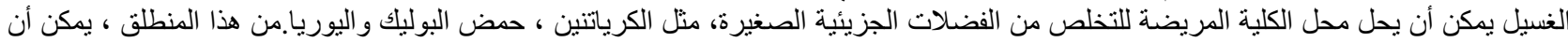

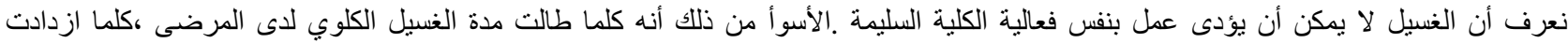
مضاعفاتهم في ذللك. هناك بعض العلاج البديل للغسيل.

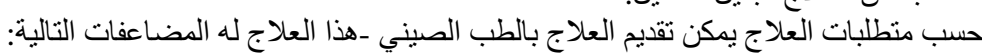

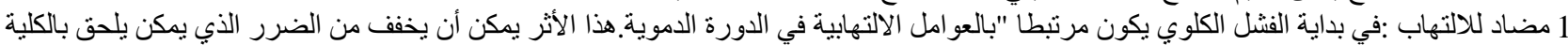
ويجعل الدورة الدموية تعود لطبيعتها.

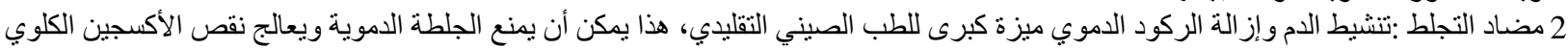

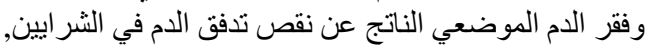

\section{Appendix (3) Teachers' Questionnaire}

\section{Dear Respondent}

The questionnaire attached herein is related to the study entitled "The Impact of Translation on Developing ESP Medical Learners' Comprehension Skills". The study aims at exploring the effect translation can have on the comprehension skills of ESP medical learners and how it can help students in reading comprehension and medical terminologies.

Please read each statement carefully and place a check mark $(\sqrt{ })$ under the column that indicates your true response to each statement. Your answer to each statement is going to be used for research purposes only, and your valuable feedback will be highly appreciated. 


\section{Personal Details}

Name:

Nationality:

Job Title:

Academic qualifications:

Years of Experience:

First: Most students encounter difficulties in understanding medical terminologies

\begin{tabular}{|c|c|c|c|c|c|}
\hline Statement & $\begin{array}{l}\text { Strongly } \\
\text { agree }\end{array}$ & Agree & $\begin{array}{l}\text { Partially } \\
\text { agree }\end{array}$ & Disagree & $\begin{array}{l}\text { Strongly } \\
\text { disagree }\end{array}$ \\
\hline $\begin{array}{l}\text { 1. Most students encounter difficulties in ESP } \\
\text { medical classes. }\end{array}$ & & & & & \\
\hline $\begin{array}{l}\text { 2. Translation in the ESP medical classes can help } \\
\text { learners better comprehend the medical reading } \\
\text { texts. }\end{array}$ & & & & & \\
\hline $\begin{array}{l}\text { 3. A limited use of L1 enables learners better } \\
\text { understand medical terminologies. }\end{array}$ & & & & & \\
\hline $\begin{array}{l}\text { 4. Without grasping the medical terms, students } \\
\text { will end up disappointed with their ESP courses. }\end{array}$ & & & & & \\
\hline $\begin{array}{l}\text { 5. Most ESP teachers find difficulty in } \\
\text { understanding the subject-matter of ESP texts. }\end{array}$ & & & & & \\
\hline $\begin{array}{l}\text { 6. ESP medical reading is perhaps one of the most } \\
\text { challenging skills in terms of L2. }\end{array}$ & & & & & \\
\hline
\end{tabular}

\section{Second: Translation in ESP medical classes can be a facilitating instructional tool}

7. A principled use of mother tongue in an ESP reading class is an aid for weak learners.

8. Using translation in ESP classes would encourage students to do their homework.

9. Using translation in an ESP reading lesson will improve student' performance in class work and quizzes.

10. Translation of medical terms would give learners the gist of a text.

11. Translation can help ESP learners enhance and reinforce reading skills and strategies.

12. By using translation, the teacher can establish a close rapport with students.

13. The students' attitudes towards the use of mother tongues in their ESP classes are positive.

14. By using L1 in an ESP class, students would be more attentive and responsive.

15. The use of mother tongue would decrease rote learning. 
16. Using translation in ESP classes is
advantageous for both the teacher and the learner.

\section{Third: Translation can be motivating for ESP medical learners}

17. The use of L1 is facilitative for learning other language skills.

18. Translation in an ESP medical class helps learners formulate and articulate their ideas more precisely.

19. The negative connotations associated with translation in ESP classes are changing.

20. Translation can instill confidence in students.

21. Translation can stir students' curiosity for more knowledge.

22. A confined use of L1 would empower students for self-instruction.

Fourth: By using translation in ESP medical classes, students can avoid shortcomings of machine translation.

23. There are many drawbacks of MT because it lacks the human touch.

24. MT provides only literal word for word translation and is unable to understand the complexities and nuances of language.

25. A machine translated text must be reviewed and edited by a competent translator.

26. The software cannot comprehend context or solve ambiguity issues.

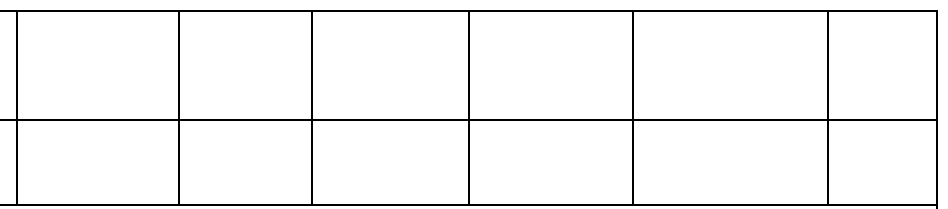

Fifth: Translation of medical terms meet learners' needs

27. The use of L1 takes into account the realities of ESP learning situation.

28. Translated medical terms can aid learners in doing research and in career development.

29. By using translation, students can have a fair access to the course and assessment.

30. Translation can enable learners to compare and contrast medical-scientific concepts, and thereby, expand learning views.

31. Translation can help in developing lesson plans and help to clarify the purposes of the course.

32. Interpretation in ESP medical classes can help in framing the course objectives in open-ended terms, so enabling learners to achieve at least something.

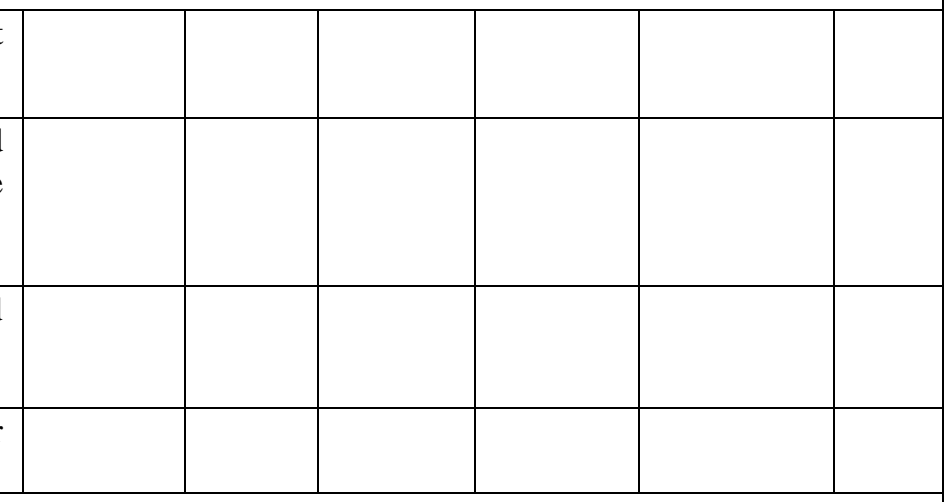

Comments: 